\title{
Ownership control of foreign affiliates: A property rights theory perspective
}

\author{
Nigel Driffield ${ }^{\mathrm{a}}$, Tomasz Mickiewicz ${ }^{\mathrm{b}, *}$, Yama Temouri ${ }^{\mathrm{b}}$ \\ a Warwick Business School, Warwick University, UK \\ ${ }^{\mathrm{b}}$ Economics, Finance and Entrepreneurship Group, Aston Business School, Aston University, Birmingham B4 7ET, UK
}

\section{A R T I C L E I N F O}

\section{Article history:}

Received 6 July 2015

Received in revised form 24 August 2016

Accepted 25 August 2016

Available online 28 August 2016

\section{Keywords:}

Foreign direct investment

Ownership

Ownership change

Property rights theory

Incomplete contracts

Corruption

Financial markets
A B S T R A C T

This paper applies property rights theory to explain changes in foreign affiliates' ownership. Post-entry ownership change is driven by both firm-level characteristics and by the differences in the institutional environments in host countries. We distinguish between financial market development and the level of corruption as two different institutional dimensions, such that changes along these dimensions impact upon ownership change in different ways. Furthermore, we argue that changes in ownership are affected by the foreign affiliate's relatedness with its parent's sector, as well as by the affiliate's maturity. We use firm level data across 125 host countries to test our hypotheses.

(C) 2016 The Authors. Published by Elsevier Inc. This is an open access article under the CC BY-NC-ND license (http://creativecommons.org/licenses/by-nc-nd/4.0/).

\section{Introduction}

Firm ownership remains a core construct in the international business (IB) literature (Aguilera \& Crespi-Cladera, 2016). The need to retain ownership and control of firm-specific assets is at the core of internalisation theory and is a founding pillar of the dominant paradigms in IB. Indeed, as discussed in the recent retrospective by Brouthers (2013), the large literature on entry modes has explored ownership decisions at the point of entry, particularly with the aid of transaction cost theory. However, there is limited understanding of how multinational enterprises (MNE) and local partners adjust their ownership shares as the external environment changes.

The existing theory on ownership change builds primarily on the tradition of Johanson and Vahlne (1977, 2009) who emphasise experiential learning and the evolutionary aspects of the process of ownership structure adjustment. However, the existing literature treats the evolution of foreign presence in a location as being, ceteris paribus, an incremental process of increased commitment. Accordingly, many studies adopt a theoretical framework that is in line with the Uppsala model (see e.g., Brouthers \& Bamossy, 1997; and Globerman \& Shapiro, 2003), which argues that firms internationalise incrementally based on their ability to

\footnotetext{
* Corresponding author.

E-mail addresses: nigel.driffield@wbs.ac.uk (N. Driffield), t.mickiewicz@aston.ac.uk (T. Mickiewicz),y.temouri1@aston.ac.uk (Y. Temouri).
}

successfully leverage their ownership advantages into new markets. However, to use this argument in order to explore the nature of the relationship between experience and affiliate ownership is, as Birkinshaw and Morrison (1995) point out, misleading. Rather, it is important to emphasise that the process of ownership change is driven by a variety of factors, resulting in an increase or a decrease in shares held by the foreign investor over time. Importantly, these follow not only the foreign investor's strategy but are co-determined by the local partner's incentives and motivation in holding the remainder of the affiliates' ownership shares. We incorporate this aspect into the analysis in order to consider the relative value of both the foreign and the local partner's contributions at the affiliate level. We argue that the evolution of the relative value of these contributions varies not only due to firm-level features and processes (relatedness of affiliate to parent and maturity of the affiliate), but also due to the institutional environments. Our study, therefore, contributes to the literature on internationalisation and ownership change in several ways.

First, we conceptualise post-entry changes in foreign affiliate ownership with the aid of property rights theory. Indeed, we seek to develop this literature in line with the findings of Beamish and Lupton (2016) who argue that it is important for future theory building on cooperative strategies in IB to focus research "on what is best for the agreement, or joint venture (JV), rather than what is good for either the foreign or local partner" (Beamish \& Lupton 
2016: 173). Building on this perspective, we argue that much of the existing literature, views ownership structures only from the perspective of the foreign partner (i.e. parent MNE), while the local partner (i.e. host country partner) is equally important. It is necessary therefore to expand our conceptual understanding. We posit that the property rights theory is a perspective that fits this suggested purpose, and we use this theory to conceptualise postentry changes in foreign affiliate ownership. This allows us to develop arguments to extend the traditional analysis centred on transaction costs (Brouthers, 2002) in order to consider the optimal distribution of ownership shares, emphasising effective responses to the problem of incomplete control. We use insights gleaned from property rights theory to investigate firm level and country level drivers of changes in ownership structure. In doing so, we explore the applicability of the property rights theory to the core IB theme of firm ownership (Antràs, 2014). Our main argument is that changes along the institutional dimensions and to the firm-level characteristics affect the relative value of the local and foreign partners' contributions and their outside options (e.g. sources of finance) in a non-symmetric manner.

Second, we extend the literature, building on Hoskisson et al. (2013), by contrasting the changes in the general quality of host country institutions that affect contracting opportunities, with the impact of improved financial markets in the host countries. We posit that financial market development is a distinct factor in explaining ownership change. In many emerging market economies, the quality of the financial sub-systems may exceed the overall institutional quality (Glaeser, Johnson, \& Shleifer, 2001) and the two systems may well evolve independently of each other. This links with arguments of Cantwell, Dunning, and Lundan (2010), who explore the co-evolution of institutions and inward investors.

Third, by focusing on changes in ownership structure, we can better isolate institutional effects from static country characteristics. For example, institutional quality measures, when captured in levels are strongly correlated with level of development, as documented by institutional theorists (e.g., North, 1990). This confounding effect no longer applies to changes in institutions. Likewise, the dynamic approach enables us to incorporate the impact of the increasing maturity of the foreign affiliate, and also how outcomes of these processes differ for firms that are characterised by higher relatedness, building on the concept utilised by Malhotra and Gaur (2014).

We have annual observations of ownership shares for 53,625 foreign affiliates in 125 countries in our sample period of 20022012, whereas previous studies have mostly relied on information at the time of investment. Utilising this data, we test our hypotheses relying on the multinomial logit estimator. Our core findings, in contrast with the earlier literature, are that an increase in corruption in the host country results in a lower likelihood of a multinational reducing its holding to become a minority partner. In contrast, improvements in local capital markets make such a move more likely, as it enhances access to finance for local firms. At the micro-level, we find that maturity of firms makes an adjustment towards minority foreign control more likely and higher relatedness between the affiliate's and the parent's activities makes an adjustment towards minority foreign control less likely. Our results are detailed below and explained with the aid of property right theory.

The paper is organised as follows. We first discuss the theoretical framework and derive our hypotheses. In the subsequent section we describe the data and methodology. The final sections present and discuss the results, followed by concluding remarks.

\section{Property rights theory and ownership structures}

Property rights theory (Grossman \& Hart, 1986; Hart, 1995) shares its essential premise with transaction cost theory (Williamson, 1985) in emphasising that contracts are always incomplete. This places the focus on ownership, since rights to income streams may not always be protected by arms' length contractual arrangements. The distribution of ownership rights becomes crucial in the presence of incomplete contracts and where investments by partners are observable but not verifiable (Hart, 1995, pp. 29 and 36). Property rights theory stresses that it is optimal for ownership control to rest with those who have the greatest impact on the value of the venture and whose output is most difficult to measure and verify (Milgrom \& Roberts, 1992, p. 311 ). In addition, the partners' contributions to value added need to be considered in conjunction with their outside options (De Meza \& Lockwood, 1998). These factors determine the nature of the control that partners exert over an investment, which follows from ownership patterns. This is explored empirically by Driffield et al. (2014), but we seek to build on this, developing arguments from Aghion and Holden (2011); Grossman and Hart (1986); Hart (1995). Despite their obvious appeal, applications of property rights theory to internationalisation issues are scarce and are either of theoretical character (Antràs, 2005, 2014) or relate to single country empirical studies (Feenstra \& Hanson, 2005). ${ }^{1}$

Building on Carson and John (2013), we argue that the problem of efficient allocation of control rights within affiliates or JVs is analogous to the problem of control rights between a MNE and a local firm in the context of outsourcing. Furthermore, consistent with Driffield et al. (2014), the optimisation of ownership structure of affiliates or JVs can be analytically separated into two different parts: (i) that of control rights which typically come with majority control (see: Gaur \& Lu, 2007), which is the property rights question, and (ii) that of specific percentages assigned to partners once the majority ownership issue is resolved - which may be seen more as an agency theory question. This distinction is consistent with the empirical evidence in two ways. First, the issue of majority control is often most contentious in JVs and mergers and acquisitions. Second, the distribution of ownership shares is non-normal, with peaks on either side of $50 \%$ (for further discussion see Driffield, Mickiewicz, \& Temouri, 2014). This indicates, as one would expect, that the majority/minority distinction is critical from a theoretical as well as an empirical perspective. Although ownership is reported as a continuum, there is great significance attached to certain percentages, particularly around the majority ownership threshold (Bishop, Filatotchev, \& Mickiewicz, 2002).

At the same time, according to property rights theory, the allocation of control rights should follow the relative capacity of the respective partners to positively influence the value of the venture at the margin. Yet evaluating these impacts remains difficult, even where the foreign partner's contribution is generally accepted to be more significant. Antràs (2005) illustrates this point using examples from sectors where product development or international marketing are core to the business and central to the development and amplification of firm specific assets. Yet even in these sectors, the contribution of the local partner remains significant, particularly when driven by local knowledge and resources (Feenstra \& Hanson, 2005).

\footnotetext{
${ }^{1}$ In particular, we follow Antràs (2014), who discusses in detail the application of Grossman and Hart (1986) to the analysis of international trade and the coordination of global value chains.
} 


\subsection{Dimensions of the host country institutional environment}

Property rights theory emphasises the transactions-relevant attributes of business partners, which need to be seen in the context of outside options. Outside options are in turn shaped by the institutional environment (De Meza \& Lockwood, 1998). Carson and John (2013) note that there is potentially a wide range of unexplored issues within IB related to the role of institutions, to which property rights theory may be applied.

Institutional quality and its relationship to both IB theory and practice is a prime example of this. Institutional quality in a given country may impact on foreign and local firms differently, both in terms of its importance, and the dimensions of the impact. The framework of Cuervo-Cazzura and Dau (2009) or Dau and CuervoCazurra (2014) highlights how improvements in various aspects of institutional quality can be expected to have heterogeneous effects at the firm level. For example, improvements in capital markets disproportionately benefit local firms, who are mostly tied to their local markets. Conversely, foreign firms with less knowledge of the host country's informal institutions will be benefiting disproportionately less from their improvements.

The central tenet of our argument is that effective institutions protect property rights and facilitate contract enforcement, imposing penalties on corruption and reducing transactions costs. However, while Brouthers $(2002,2013)$ has explored how different ownership structures develop in response to different transaction costs associated with various aspects of institutional quality, building for example on Khanna and Palepu (2010) and Eden and Miller (2004), we seek to develop this further. Peng and Heath (1996) argue that within a strategic choice setting, adjustment in ownership structure follows the actual or perceived changes in prevailing institutional environments. We seek to coalesce these arguments using property rights theory.

Hoskisson et al. (2013) highlight the juxtaposition of two elements of the institutional environment in emerging markets; namely the risks associated with low levels of property rights protection and the financial risk associated with thin or poorly developed financial markets. Applying this to ownership decisions amid institutional changes, our main argument is that the developments along these two dimensions do not need to be strongly correlated (Claessens, Demirgüç-Kunt, \& Huizinga, 2001; Driffield et al., 2014). We argue and demonstrate in our analysis that improvements in institutional quality and in the financial markets need to be viewed as two separate dimensions. This is similar to Peng, Lee, and Wang (2005), who contrast the broader institutional features which affect product markets with the more specific institutional features related to financial markets. Both may, from the perspective of foreign investors and local partners, produce different outcomes (Khoury \& Peng, 2011; Makhija \& Stewart, 2002). Likewise, Cantwell et al. (2010) explore the evolution of both financial and non-financial institutions alongside the evolution of foreign affiliates' strategies.

\subsection{Institutional and financial market drivers of change in ownership control}

Let us first consider a possible transaction costs argument related to institutional quality as proxied by corruption. What happens when institutional quality deteriorates so that the level of corruption increases? To paraphrase Leo Tolstoy's Anna Karenina: transparent institutional environments are all alike, while every corrupt environment is corrupt in its own way. In other words, efficient institutions imply transparent and universal rules, while inefficient ones imply localised knowledge and relationships. Thus, as corruption increases, the environment becomes more opaque to the foreign investor.

Transactions costs approach, or related agency approach to this problem would emphasise the increased risk of opportunistic behaviour by the local partner, with increased transaction costs incurred by the foreign partner. Local partners have a better understanding of local conditions, and this gives them additional advantage in such relationships if institutions weaken. As institutional quality and the transparency of business dealings decline, monitoring the local partner's behaviour becomes more problematic, and this is more likely to lead to a transfer of resources out of the venture by the local partner (Kogut 1988). An organisational solution to this is to give higher shares to local partner. To put it differently, a reduction in local partner's share becomes less likely (Meyer, Mudambi, \& Narula, 2011), because higher shares of the local partner implies that the incentives for opportunistic behaviour diminish. This is an argument, which can be seen as combining the transaction costs and the agency theory perspectives (see also: Driffield et al., 2014).

In contrast, we may construct the property rights argument as related to the risk of both partners being expropriated by the government or its agents; the risk which increases when the institutional quality deteriorates. Historical evidence for this may be derived, for example, by focusing on the early period of liberalisation in China, when the institutional protection of domestic private property was still negligible. We are interested in which way the ownership of firms may adjust to such conditions. In that period, foreign dominant ownership was actively sought after by local partners, and one of the reasons was that the presence of a foreign partner guaranteed security of ownership: "private entrepreneurs might have desired FDI arrangements as a way to protect their assets" (Huang, 2003: 201). Acquiring a foreign partner alleviated not only the risk of outright expropriation but also of tunnelling value from the company and its private shareholders to state shareholders or stakeholders, as again exemplified by Huang (2003). At that time, the only alternatives were by way of informal investment or by hiding private ventures in disguised forms of state ownership.

Property rights theory can be used to generalise this as follows. In environments that are characterised by low institutional quality, it is the foreign partner that may be better protected from expropriation risks. Foreign partners may be in a stronger position than their local partners due to wider reputational effects of explicit or implicit expropriation (Driffield, Mickiewicz, \& Temouri, 2013). While under corrupt governments such expropriation is possible, it may be less likely when the foreign partner has high ownership stake in the foreign affiliate.

In summary, the question becomes whether property rights or transaction costs - agency arguments dominate in the explanation of changes in ownership structure triggered by change in corruption levels. According to transaction cost/agency theory, foreign partner firms would respond to deteriorating institutional quality and increased opaqueness in a host country by reducing their ownership share and increasing the share of the host country firm in order to incentivise the local partner to act in the best interest of the firm. In contrast, property rights theory emphasises the relative contributions of the two parties, and in this case the increased contribution of the foreign partner, through the greater security attached to foreign ownership. For example, foreign investors are backed by their home country governments, and in the case of countries characterised by instability, by investment treaties between governments to prevent expropriation. Therefore, as institutional quality declines, the relative importance of the foreign partner increases. This leads us to propose our first hypothesis as a set of two alternatives: 
H1a. As corruption in the host country worsens, the shift from majority to minority foreign ownership becomes more likely (costs of opacity argument).

H1b. As corruption in the host country worsens, the shift from majority to minority foreign ownership becomes less likely (risks of expropriation argument).

Any adjustment in ownership structure presumes a functioning financial market, such that equity in the affiliate can be traded. Thus, the cost of adjustment related to financial markets may become a critical factor. Baker, Foley, \& Wurgler, 2008, for example, show a model of the MNE acting as a capital arbitrageur, raising finance in markets where capital is cheap or where equity can be sold at a premium, and then transferring that capital to locations where local capital is expensive and the expected returns considerably higher. If ease of adjustment is the critical factor, we would expect that both downward and upward adjustment in ownership shares of foreign owner becomes more likely.

Financial market development may have additional significance. With weak financial markets, the corporate governance challenges faced by emerging market firms are well documented (Hoskisson, Wright, Filatotchev, \& Peng, 2013). Here, as well as providing finance, a key contribution of foreign investors may be to signal the governance quality so that external finance may be acquired at lower cost. This extends the analysis of emerging market firms of Khanna and Palepu (1999), based on the signalling approach of Peng and Su (2014). Consistent with this, the contribution of the foreign firm, both in terms of the direct provision of capital, but also of signalling and monitoring, may be a key determinant of the prevailing ownership structure, affecting the allocation of property rights where financial markets are weak.

However, with property rights theory and the literature which develops from it, it is also important to take into account the outside options in order to appropriately incentivise partners (De Meza and Lockwood, 1998). For example, Huang (2003) makes a strong argument by demonstrating that the initial flow of FDI to China was, to a large extent, the result of private domestic firms in that country not being able to secure financing and working capital for their operations. Following this logic, we expect that in environments where local financing opportunities for local private companies improve, those ventures, initially dominated by foreign partners, will experience an evolution in ownership, with local equity either replacing or diluting foreign equity.

This suggests that as the local financial market develops, the importance of foreign investors declines in the sense that local partners are less in need of finance from the foreign partner as well as in need of signalling governance quality. In turn, this reduces the relative value of the foreign partner's contribution. Therefore, building on the analysis of Henisz (2000), we argue that local financial development is disproportionately more beneficial to the local partner. MNEs can by definition access financial markets at home and abroad, while local firms are typically limited to their own financial markets. Moreover, financial markets not only provide access to finance but also help to efficiently allocate resources by providing screening and monitoring of investment decisions. As Claessens et al. (2001) discuss in their seminal work on governance in emerging markets, the better the local financial markets work, the better the outside evaluation and financial market responses to investment projects. Again, this implies that the importance of the signalling effect of foreign partner's presence diminishes.

Property rights analysis therefore suggests that as local financial markets improve, the marginal distinct contribution of the foreign partner, not only in terms of providing capital but also with regard to monitoring and signalling, declines. This leads to our second hypothesis:

H2. As equity markets in the host country improve, the shift from majority to minority foreign ownership becomes more likely.

\subsection{Firm-level drivers of change in ownership control}

We now explore the importance of maturity of the joint project in the context of the ownership structure. We contrast the perspective we derive from property rights theory with one of the dominant perspectives in IB, namely the Uppsala model (Johanson \& Vahlne, 1977, 2009). The latter would lead to the conclusion that foreign investor's commitment increases over time as the foreign partner gains experience and the affiliate becomes more embedded.

However, reflecting on control patterns and strategies of subsidiaries, Ambos, Andersson, and Birkinshaw (2010), Birkinshaw and Morrison (1995), and Nobel and Birkinshaw (1998) argue that experience better informs strategy, but that informed strategy is neither equivalent to the continuation of the status quo, nor to any form of a linear evolution towards more control by the parent company. Their arguments can be extended to explore changes in ownership structure. In this context, we highlight the importance of experience of both parties in explaining prevailing ownership structure, in terms of the incremental, but not necessary unidirectional, adjustment towards the optimal solution. This may involve adjustments in either direction from the initial ownership agreement. In order to consider this question using property rights theory, we build on the existing literature which considers the ownership structure, in terms of the respective bargaining positions of the two parties (Driffield et al., 2014). This emphasises that the key contributions of the foreign partner is typically capital, technology, and international marketing, while the key contribution of the local partner is local knowledge.

These respective contributions are crucial to the venture. In particular, knowledge transfer by foreign firms into a host country follows particular patterns, depending on the life cycle of the products concerned. This may involve for example a large initial investment, which declines over time, or a low investment that increases as the firm understands more about the host environment. Such an investment relates mainly to technology and may be embedded in sophisticated product design (e.g. Buckley \& Casson, 2010; Driffield, Love, \& Menghinello, 2010). It may also include managerial and organisational knowledge and marketing; yet, as the foreign affiliate matures, both become absorbed and embedded within it (Antràs, 2005). Irrespective of the technological development path of the affiliate, as a project matures, the technology it employs is likely to become more standardised and adapted to local conditions (Fang, Wade, Delios, \& Beamish, 2013); it is also better understood locally and, crucially, is less cutting edge. In turn, this requires lower levels of international technology transfer from the foreign parent. Consistent with property rights theory, controlling ownership by the foreign partner becomes less likely.

We therefore argue that the property rights approach may help us to understand the link between the maturity of the project and the evolution of ownership structures. This nuances the predictions based on the standard approaches adopted in IB developed from Johanson and Vahlne (1977), highlighting that typical changes in the respective contributions of the two parties over time makes the foreign partner less likely to retain a controlling stake.

Consider for example the situation where the foreign firm starts out as the majority partner. The scenario here is similar to Gans 
(2005) and Maskin and Tirole (1999). This analysis allows for interim bargaining, as the relative contributions of the two parties change. In our context it reflects the investment patterns of both parties, and their changing contributions (e.g., Leahy \& Montanga, 2015). Consistent with the argument we presented above, and building on the analysis of Boddewyn (1983), we focus on the value of the corresponding contribution, and therefore the value of controlling ownership: the latter declines with respect to the foreign partner. Maturity increases the relative weight of the contribution of the local partner, as local factors may now dominate foreign (standardised) technology. The knowledge of the local partners becomes more important, and with it the value of their contribution. This ceteris paribus triggers the downward adjustment of the foreign share in the existing equity structure.

To conclude, we contrast the arguments supporting gradual increase of foreign partner commitment with those supporting the decrease of relative significance of foreign partner contribution. This leads to our third hypothesis presented as two alternatives:

H3a. The more mature the local affiliate, the more likely it is that there will be is a shift from minority to majority foreign ownership (Uppsala model perspective).

H3b. The more mature the local affiliate, the more likely it is that there will be is a shift from majority to minority foreign ownership (property rights theory perspective).

Our final hypothesis extends our analysis from experience to consider relatedness, i.e. whether the parent firm and the host country firm operate in the same core industry. Relatedness in this context is widely seen as an important construct (see e.g. Malhotra \& Gaur, 2014). We focus our attention on the impact of relatedness of the foreign affiliate on the evolution of ownership over time.

Andersson et al. (2005) maintain that sharing the same industry makes it more likely that knowledge transfer will occur, in both directions (Andersson, Forsgren, \& Holm, 2007; Driffield et al., 2010; Mudambi \& Navarra, 2004). Arguably, firms develop strategies to mitigate risks in such investments from the start, and establish stable ownership structures that best address the trade-off between risk and opportunism (Zhou, 2014). One could therefore assume that this influences not only the initial ownership structure, but also the likelihood of changes in that structure as the relationship develops, making a change in a firm's holdings less likely. It follows from this argument that such investments that are characterised by relatedness are less likely to be subject to post-establishment ownership control change.

However, property rights theory enables us to come with sharper predictions. Again, we argue that the key factor is the relative contribution of the respective partners in a JV. We posit that greater relatedness between the parent and the specific host country JV amplifies and sustains over time the marginal value of the foreign partner's contribution. ${ }^{2}$ Where a foreign affiliate is part of the parent MNE's core activity, this is related to higher levels of particularly valuable technology transfer (Driffield et al., 2010; Driffield, Love, \& Yang, 2016). This in turn increases the value of the parent's contribution, implying a larger ownership share, and also makes it more likely that this share will be sustained over time. Thus, we argue that higher levels of relatedness lead to higher sustained ownership by the foreign partner. Therefore, within the

\footnotetext{
2 We note an important, alternative line of reasoning by Malhotra and Gaur (2014) who observe that "the relatedness of the acquirer and the target affects information asymmetry and the associate risks that acquirers faces" (Ibid., p.197). It follows therefore that the higher relatedness implies lower moral hazard risks due to the investor's superior knowledge of the acquired firm's profile, which may also lead to higher stakes, albeit for different reasons that we emphasise.
}

realms of possible adjustments, it is the downwards adjustment that is particularly less likely to occur. This leads to our final hypothesis:

H4. Parents and their affiliates with high relatedness exhibit a lower likelihood of changing from majority to minority foreign ownership.

\section{Data and methodology}

Our data sample includes 122 home countries and 125 host countries. It is drawn from ORBIS, which is a comprehensive, rich, firm-level dataset. It is provided by Bureau van Dijk (BvD), ${ }^{3}$ a leading electronic publisher of annual account information on private and public firms around the world. The data provides information on the affiliates of a given company, together with the ownership structure. It is collected from various sources, including national official bodies in charge of gathering company accounts data. The data are then compiled and organised by BvD in a consistent format, following strict guidelines, making it comparable across countries. We have the timing of the investment decision given by the date of incorporation of the venture and we trace changes in ownership and the investment in foreign and domestic capital throughout the period. ${ }^{4}$

The average foreign ownership of affiliates is relatively high at $75 \%$ and we observe a change in ownership in $58 \%$ of all affiliates. This change in ownership could be a few percentage points, or something more significant up to and including a move to wholly owned status or reduction to zero (i.e. exit). The average adjustment in shares is $30 \%$. This information clearly indicates that adjusting ownership after entry can be seen as a relatively common business practice (Benito, Petersen, \& Welch, 2009). More importantly for our analysis, $8 \%$ of the sample accounts for affiliates that switch from minority to majority ownership or vice versa.

Table 1 presents descriptive statistics regarding the coverage of our data and the differences in institutional quality. As one would expect, there are significant differences between the highest and lowest values of institutional quality across countries, providing a good deal of spread in terms of both the home and the host country values.

Fig. 1 shows a scatter across countries along the two dimensions of institutional quality. It shows the average annual change over the period 2002-2013 in both the ease of access to financial markets and in the corruption index (please see Section 3.1 below for exact definitions of these variables). Importantly for our econometric design, Fig. 1 shows little correlation between the two dimensions ( $\mathrm{R}$ squared is $4.2 \%$ ), confirming the argument we identify above: financial markets may be seen as an autonomous part of the institutional environment, evolving in a relatively independent way from overall institutional quality. Presenting over 100 countries would clutter the diagram, especially in the centre, so we show the largest twenty economies plus outliers, i.e. countries located furthest from the centre of the graph on either one or both dimensions where institutional environment change was most pronounced.

For example, China, Qatar, Uruguay and Ecuador are countries where both the effectiveness of their equity markets improved and the level of corruption diminished. Zimbabwe and Malawi represent the case of some progress in fighting corruption coupled with a weakening of local equity markets. In two Latin American

\footnotetext{
${ }^{3}$ ORBIS is available via the provider's website at www.bvdep.com.

${ }^{4}$ We are able to trace ownership throughout the period by using earlier releases or archived information of the dataset for each firm.
} 
Table 1

The Geographical distribution of firms in the sample, 2002-2013.

\begin{tabular}{|c|c|c|c|c|}
\hline Country & Parent firms & Affiliates & $\begin{array}{l}\text { Corruption index } \\
\text { Mean (s.d.) }\end{array}$ & $\begin{array}{l}\text { Equity market index } \\
\text { Mean (s.d.) }\end{array}$ \\
\hline OECD Europe & 30,279 & 18,247 & $3.05(1.16)$ & $4.65(1.03)$ \\
\hline OECD North America & 2040 & 765 & $2.51(0.50)$ & $5.35(0.69)$ \\
\hline OECD Asia & 1005 & 616 & $3.80(0.68)$ & $5.01(0.90)$ \\
\hline OECD (Australia, New Zealand, Chile, Mexico, Israel) & 465 & 658 & $3.08(1.24)$ & $5.01(0.90)$ \\
\hline OECD Total & 33,789 & 20,286 & $3.06(1.14)$ & $4.76(1.01)$ \\
\hline Emerging Far East \& Central Asia & 1304 & 6337 & $4.76(0.92)$ & $4.36(1.25)$ \\
\hline Emerging Africa \& Middle East & 192 & 263 & $4.99(0.71)$ & $3.82(1.12)$ \\
\hline Emerging Eastern Europe & 1831 & 25,872 & $4.96(0.41)$ & $3.52(0.86)$ \\
\hline Emerging South \& Central America & 1178 & 2479 & $4.78(0.69)$ & $3.47(0.96)$ \\
\hline Emerging countries Total & 5060 & 33,339 & $4.88(0.76)$ & $3.82(1.16)$ \\
\hline
\end{tabular}

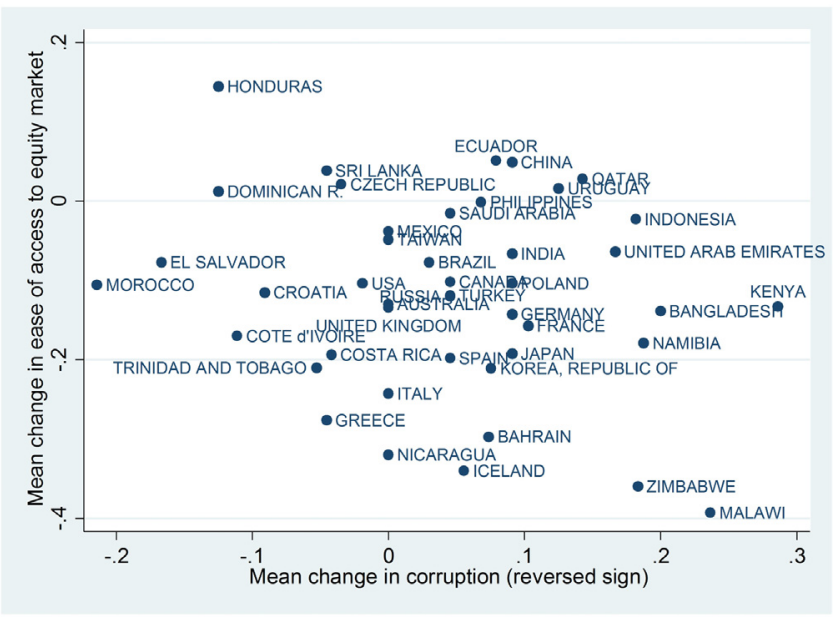

Fig. 1. Change in institutional quality, 2002-2013.

countries, Honduras and Dominican Republic, we see an improvement in equity markets but growing corruption. And finally, Morocco, Cote d'Ivore, El Salvador, Trinidad and Tobago and Greece experienced a deterioration in their equity markets and growing corruption.

Notably, most developed countries are clustered in the centre of the graph. They have experienced less institutional change; most of the institutional dynamics have been amongst the emerging market economies.

Table 2 provides a correlation matrix. Most of the correlations between explanatory variables are weak and we conducted a series of VIF calculations. All of these are below 2.5 and do not suggest multicollinearity problems. ${ }^{5}$

\subsection{Dependent variable}

We observe the parent firm's ownership percentage in its affiliate for every year during the sample period. This percentage ownership can stay constant year-on-year, can change upwards or downwards, or be a sequence of the two during the period. Using this detailed information we estimate a multinomial logit model, where we categorise the discrete indicator of a change in foreign

\footnotetext{
${ }^{5}$ One exception are the correlations between home and host financial performance. Correlations are marginally significant, but present no collinearity problem due to the cross sectional variation in the measures.
}

ownership control, as follows: (i) switches from majority to minority ownership (ii) switches from minority to majority ownership or (iii) no change between minority and majority. While interpreting majority ownership as ownership control is a simplification, it is a reasonable one for most cases (see Bishop et al., 2002; for further discussion). As an empirical extension and robustness check we also create an alternative categorisation by using the annual change in foreign ownership percentage to distinguish between an increase, a decrease and no change.

\subsection{Independent variables}

There are two sets of variables that relate to our central hypotheses, namely at the institutional and firm-level. Firstly, we have the vector of the general institutional quality and of financial market measures, all in first (annual) differences. These come as two pairs, available for both the host and the home country. However, our primary interest is in host country indicators (hypotheses 1 and 2). We discuss these measures next.

\subsubsection{Macro level: corruption and ease of accessing a local equity market}

In testing Hypothesis 1 we measure general institutional quality using the level of corruption. In the IB literature, corruption has been seen as the single most appropriate indicator of institutional quality, as it distils the impact of underlying institutional inputs (including the poor protection of property rights and excessive or arbitrary regulation) into one output indicator that describes the quality of the interface between businesses and public administration (Cuervo-Cazurra, 2006; Cuervo-Cazurra, 2016; Habib \& Zurawicki, 2002; Javorcik \& Wei, 2009; Tanzi, 1998; Zhao, Kim, \& Du, 2003;). At the same time, bribery may be seen as representing the normative aspect of institutions (Estrin, Korosteleva, \& Mickiewicz, 2013; Gaur and Lu, 2007).

We rely on data on freedom from corruption from the International Risk Country Guide compiled by the Political Risk Services Group (PRS), but the corruption index is consistent with measures available either directly from Transparency International or from Heritage Foundation/Wall Street Journal. ${ }^{6}$ Accordingly, we include the corruption index $(\mathrm{CI})$ for host and home countries prepared by the PRS Group. The corruption index ranges from $1=$ low level of corruption to 7 =high levels of corruption. This

\footnotetext{
${ }^{6}$ While these data capture the perceptions of business environment, the issue of subjectivity is more apparent than real, since the business decisions are driven by these same perceptions of the decision makers. The methodology used to combine existing surveys into country-level scalars was developed by Transparency International and is subsequently used by other public and private agencies that report institutional indicators.
} 
Table 2

Descriptive statistics and correlation matrix.

\begin{tabular}{|c|c|c|c|c|c|c|c|c|c|c|c|c|c|}
\hline Variable & Mean & Std dev & 1 & 2 & (3) & (4) & (5) & (6) & (7) & (8) & (9) & $(10)$ & $(11)$ \\
\hline 1. Ownership share & 75.60 & 31.53 & 1 & & & & & & & & & & \\
\hline 2. Relatedness & 0.22 & 0.41 & $0.02^{* *}$ & 1 & & & & & & & & & \\
\hline 3. Maturity & 0.55 & 0.50 & $-0.07^{* *}$ & $-0.02^{* *}$ & 1 & & & & & & & & \\
\hline 4. International Experience & 6.54 & 14.46 & $-0.09^{* *}$ & $-0.01^{* *}$ & $0.03^{* *}$ & 1 & & & & & & & \\
\hline 5. Host country Experience & 0.92 & 5.18 & $-0.05^{* *}$ & $-0.02^{* *}$ & $-0.02^{* *}$ & $0.53^{* * *}$ & 1 & & & & & & \\
\hline 6. High tech dummy & 0.34 & 0.47 & $-0.07^{* *}$ & $0.08^{* *}$ & $0.02^{* *}$ & $0.06^{* *}$ & $0.02^{* *}$ & 1 & & & & & \\
\hline 7. Host Corruption & 0.01 & 0.23 & $0.05^{* *}$ & 0.00 & $0.03^{* *}$ & $-0.02^{* *}$ & $0.02^{* *}$ & $-0.01^{* *}$ & 1 & & & & \\
\hline 8. Host Equity markets & -0.15 & 0.33 & -0.00 & $0.02^{* *}$ & $-0.01^{* *}$ & $0.02^{* *}$ & $0.02^{* *}$ & $0.03^{* *}$ & $0.09^{* *}$ & 1 & & & \\
\hline 9. Home Corruption & -0.02 & 0.36 & $0.01^{* *}$ & $0.01^{* *}$ & $0.03^{* *}$ & $-0.02^{* *}$ & $-0.01^{* *}$ & -0.00 & 0.00 & $0.04^{* *}$ & 1 & & \\
\hline 10. Home Equity Markets & -0.15 & 0.39 & $0.01^{* *}$ & $-0.01^{*}$ & $-0.01^{* *}$ & $-0.01^{* *}$ & $-0.01^{*}$ & $0.01^{* *}$ & $0.11^{* *}$ & $0.52^{* *}$ & $0.01^{* *}$ & 1 & \\
\hline 11. Subsidiary Profits dummy & 0.38 & 0.48 & $-0.09^{* * *}$ & $-0.08^{* *}$ & $0.07^{* * *}$ & $0.02^{* * *}$ & $-0.03^{* *}$ & $-0.02^{* * *}$ & $-0.08^{* *}$ & $-0.01^{* *}$ & $-0.01^{* *}$ & -0.01 & 1 \\
\hline
\end{tabular}

${ }^{*} \mathrm{p}<0.05$; two-tailed test.

$\mathrm{p}<0.01$; two-tailed test.

index offers an assessment of both political and financial corruption in, for example, the form of demands for special payments, and bribes connected with import and export licenses, exchange controls, tax assessments, police protection, or loans. The index also takes into account corruption in the form of excessive patronage, nepotism, job reservations, "favour-for-favours", secret party funding, and suspiciously close ties between politics and business.

In testing Hypothesis 2, we include an index measuring ease of accessing a local equity market, taken from the Global Competitiveness Report, prepared by World Economic Forum (WEF).

The WEF's characterisation of country's equity market is based on the following question included in the survey of executives: "In your country, how easy is it for companies to raise money by issuing shares on the stock market? [1=extremely difficult; 7 = extremely easy]". Both corruption and ease of financial access variables were centred on zero.

\subsubsection{Firms' level: maturity and relatedness}

Our final two hypotheses concern maturity of the project and relatedness. Relatedness is captured by the similarity between the parent's core business and the nature of the foreign investment. Specifically this concerns whether they are operating in the same core (two-digit) industry.

Maturity is measured based on an affiliate's founding year. As the resulting age-of-firm variable has a highly skewed distribution estimated mean effect would be meaningless: falling outside the mass of actual observations. Therefore, we categorise this variable into age of firms below 10 years versus 10 years and above, which roughly corresponds to splitting observations by half.

\subsubsection{Control variables}

In addition, following the literature, we introduce a number of control variables. On the macro level we add the corresponding indicators (as described in Section 3.2.1) from the home country, echoing the current state of the literature as represented by Lien and Filatotchev (2015), who relate ownership shares held by inward investors in more risky host countries to both the local conditions and to the conditions faced by the parent firms at home. Similarly, Brouthers (2002) and Lahiri, Elango, and Kundu (2014) incorporate home in addition to host country effects.

Turning to the micro level, the arguments used to develop Hypothesis 3 were related to project-specific (within-the-firm) experience that accumulates with maturity. However, we wish to check if the effects are not confounded by other types of experience. We measure local experience (outside the firm) by the number of subsidiaries in the same host country that the foreign partner has, similar to Gaur and Lu (2007). In turn, international experience is proxied by the number of subsidiaries in other countries.

For relatedness, the key confounding effect may occur if in some sectors it is more likely that foreign investors go for the same sectoral affiliation when internationalising. We therefore need to control for sectors of activity.

In addition, we include the existing ownership share. The theoretical reason for doing this is that the drivers of ownership change may be related to the pre-existing conditions based on the literature discussed above. The initial ownership structure is likely to capture all these factors well. A related empirical concern is that with any adjustment process the initial condition is likely to be important, based on optimum speed of adjustment considerations.

We control for past performance. Firms may wish to divest themselves of shares in poorly performing affiliates or to increase their share in highly profitable affiliates. Although the local partner may also seek to increase their holding in such circumstances; the foreign (MNE) partner may have a liquidity advantage. Taking all of these factors into consideration, past financial performance is likely to have some impact, but the net effect remains ambiguous. We control for it by introducing a dummy which takes the value of 1 when returns on assets (ROA) are positive (lagged one year).

Finally, we need to isolate the effects of evolving world market conditions by introducing time effects, as otherwise some changes in the local institutional environments may be confounded with global trends. Likewise, the profitability of companies may have a shared global component and we need to extract it. Furthermore, foreign investment decisions come in waves affected by global market conditions. Parallel to this, since we measure experience as 'years since the affiliate was acquired', controlling for time is important, as otherwise our experience measure could capture some cohort effects of these investment waves.

\subsection{The model}

Our model incorporates variables that capture all of the effects outlined above under Hypotheses 1-4. We relate changes in ownership structure to changes in institutional quality and in capital market effectiveness in the host (and home) countries, to maturity of the project, and to whether the affiliate is characterised by relatedness with respect to the activities of the parent. In addition, we have additional controls as discussed above, so that the impact of omitted variables bias is alleviated. 
Table 3

Results of foreign affiliate ownership control changes (Multinomial logit regressions).

\begin{tabular}{|c|c|c|c|c|c|c|c|c|c|}
\hline \multirow[b]{2}{*}{ VARIABLES } & \multicolumn{3}{|c|}{ (1) Full sample } & \multicolumn{2}{|c|}{ (2) Without Wholly-owned } & \multicolumn{2}{|c|}{ (3) Without zeros } & \multicolumn{2}{|c|}{ (4) Europe only } \\
\hline & $\begin{array}{l}\text { Majority to } \\
\text { Minority }\end{array}$ & $\begin{array}{l}\text { Minority to } \\
\text { Majority }\end{array}$ & $\begin{array}{l}\text { Difference in } \\
\text { coef. }\left(\chi^{2}\right)\end{array}$ & $\begin{array}{l}\text { Majority to } \\
\text { Minority }\end{array}$ & $\begin{array}{l}\text { Minority to } \\
\text { Majority }\end{array}$ & $\begin{array}{l}\text { Majority to } \\
\text { Minority }\end{array}$ & $\begin{array}{l}\text { Minority to } \\
\text { Majority }\end{array}$ & $\begin{array}{l}\text { Majority to } \\
\text { Minority }\end{array}$ & $\begin{array}{l}\text { Minority to } \\
\text { Majority }\end{array}$ \\
\hline Ownership share (t-1) & $\begin{array}{l}0.006^{* * *} \\
(0.001)\end{array}$ & $\begin{array}{l}-0.069^{* * *} \\
(0.001)\end{array}$ & & $\begin{array}{l}0.009^{* * *} \\
(0.001)\end{array}$ & $\begin{array}{l}-0.053^{* * *} \\
(0.001)\end{array}$ & $\begin{array}{l}0.004^{* * *} \\
(0.001)\end{array}$ & $\begin{array}{l}-0.071^{* * *} \\
(0.002)\end{array}$ & $\begin{array}{l}0.007^{* * * *} \\
(0.001)\end{array}$ & $\begin{array}{l}-0.072^{* * *} \\
(0.001)\end{array}$ \\
\hline $\begin{array}{l}\text { Relatedness with respect } \\
\text { to Parent }\end{array}$ & $\begin{array}{l}-0.202^{* * *} \\
(0.050)\end{array}$ & $\begin{array}{l}0.143^{* *} \\
(0.061)\end{array}$ & $18.800^{* * *}$ & $\begin{array}{l}-0.089 \\
(0.061)\end{array}$ & $\begin{array}{l}0.093 \\
(0.075)\end{array}$ & $\begin{array}{l}-0.201^{* * *} \\
(0.051)\end{array}$ & $\begin{array}{l}0.083 \\
(0.072)\end{array}$ & $\begin{array}{l}-0.232^{* * *} \\
(0.066)\end{array}$ & $\begin{array}{l}0.231^{* * *} \\
(0.072)\end{array}$ \\
\hline $\begin{array}{l}\text { Maturity: time since } \\
\text { initial Investment }\end{array}$ & $\begin{array}{l}0.266^{* * *} \\
(0.069)\end{array}$ & $\begin{array}{l}-0.065 \\
(0.069)\end{array}$ & $12.590^{* * *}$ & $\begin{array}{l}0.193^{* *} \\
(0.094)\end{array}$ & $\begin{array}{l}-0.005 \\
(0.071)\end{array}$ & $\begin{array}{l}0.270^{* * *} \\
(0.070)\end{array}$ & $\begin{array}{l}0.031 \\
(0.074)\end{array}$ & $\begin{array}{l}0.155^{* * *} \\
(0.059)\end{array}$ & $\begin{array}{l}-0.075 \\
(0.089)\end{array}$ \\
\hline International experience & $\begin{array}{l}0.012^{* * *} \\
(0.002)\end{array}$ & $\begin{array}{l}-0.018^{* * *} \\
(0.003)\end{array}$ & & $\begin{array}{l}0.012^{* * *} \\
(0.002)\end{array}$ & $\begin{array}{l}-0.021^{* * *} \\
(0.004)\end{array}$ & $\begin{array}{l}0.013^{* * *} \\
(0.002)\end{array}$ & $\begin{array}{l}-0.011^{* * *} \\
(0.004)\end{array}$ & $\begin{array}{l}0.012^{* * * *} \\
(0.002)\end{array}$ & $\begin{array}{l}-0.019^{* * *} \\
(0.005)\end{array}$ \\
\hline Host country experience & $\begin{array}{l}-0.015^{* *} \\
(0.007)\end{array}$ & $\begin{array}{l}-0.012 \\
(0.025)\end{array}$ & & $\begin{array}{l}-0.029^{* * *} \\
(0.011)\end{array}$ & $\begin{array}{l}0.007 \\
(0.019)\end{array}$ & $\begin{array}{l}-0.015^{*} \\
(0.009)\end{array}$ & $\begin{array}{l}-0.00 \\
(0.019)\end{array}$ & $\begin{array}{l}-0.006 \\
(0.006)\end{array}$ & $\begin{array}{l}-0.005 \\
(0.039)\end{array}$ \\
\hline High tech dummy & $\begin{array}{l}0.611^{*} \\
(0.364)\end{array}$ & $\begin{array}{l}0.281 \\
(0.594)\end{array}$ & & $\begin{array}{l}0.634 \\
(0.555)\end{array}$ & $\begin{array}{l}0.378 \\
(0.749)\end{array}$ & $\begin{array}{l}0.608 \\
(0.399)\end{array}$ & $\begin{array}{l}0.839 \\
(0.655)\end{array}$ & $\begin{array}{l}0.334 \\
(0.449)\end{array}$ & $\begin{array}{c}-0.356 \\
(0.921)\end{array}$ \\
\hline Subsidiary Profits & $\begin{array}{l}0.430^{* * *} \\
(0.051)\end{array}$ & $\begin{array}{l}0.143^{* * *} \\
(0.052)\end{array}$ & & $\begin{array}{l}0.301^{* * *} \\
(0.053)\end{array}$ & $\begin{array}{l}0.214^{* * *} \\
(0.061)\end{array}$ & $\begin{array}{l}0.440^{* * *} \\
(0.051)\end{array}$ & $\begin{array}{l}0.183^{* * *} \\
(0.058)\end{array}$ & $\begin{array}{l}0.285^{* * *} \\
(0.056)\end{array}$ & $\begin{array}{l}0.103 \\
(0.068)\end{array}$ \\
\hline Host Corruption & $\begin{array}{l}-0.252^{* *} \\
(0.120)\end{array}$ & $\begin{array}{l}-0.017 \\
(0.084)\end{array}$ & 2.340 & $\begin{array}{l}-0.125 \\
(0.135)\end{array}$ & $\begin{array}{l}-0.003 \\
(0.102)\end{array}$ & $\begin{array}{l}-0.226^{*} \\
(0.120)\end{array}$ & $\begin{array}{l}0.088 \\
(0.096)\end{array}$ & $\begin{array}{l}-0.376^{* * *} \\
(0.120)\end{array}$ & $\begin{array}{l}-0.022 \\
(0.097)\end{array}$ \\
\hline Host Equity Market & $\begin{array}{l}0.255^{* *} \\
(0.127)\end{array}$ & $\begin{array}{l}-0.339^{* * *} \\
(0.111)\end{array}$ & $12.310^{* * *}$ & $\begin{array}{l}0.326^{* *} \\
(0.152)\end{array}$ & $\begin{array}{l}-0.292^{* *} \\
(0.120)\end{array}$ & $\begin{array}{l}0.247^{*} \\
(0.129)\end{array}$ & $\begin{array}{l}-0.242^{*} \\
-0.133\end{array}$ & $\begin{array}{l}0.147 \\
(0.118)\end{array}$ & $\begin{array}{l}-0.269^{* *} \\
(0.121)\end{array}$ \\
\hline Home Corruption & $\begin{array}{l}0.357^{* * *} \\
(0.104)\end{array}$ & $\begin{array}{l}-0.323^{* * *} \\
(0.094)\end{array}$ & & $\begin{array}{l}0.161 \\
(0.131)\end{array}$ & $\begin{array}{l}-0.198 \\
(0.127)\end{array}$ & $\begin{array}{l}0.336^{* * *} \\
(0.106)\end{array}$ & $\begin{array}{l}-0.235^{* *} \\
(0.117)\end{array}$ & $\begin{array}{l}0.259 * \\
(0.140)\end{array}$ & $\begin{array}{l}-0.339^{* * *} \\
(0.104)\end{array}$ \\
\hline Home Equity Market & $\begin{array}{l}0.358^{* * *} \\
(0.125)\end{array}$ & $\begin{array}{l}-0.228^{*} \\
(0.118)\end{array}$ & & $\begin{array}{l}0.312^{* *} \\
(0.151)\end{array}$ & $\begin{array}{l}-0.234 \\
(0.168)\end{array}$ & $\begin{array}{l}0.362^{* * *} \\
(0.124)\end{array}$ & $\begin{array}{l}-0.033 \\
(0.151)\end{array}$ & $\begin{array}{l}-0.117 \\
(0.136)\end{array}$ & $\begin{array}{l}-0.170 \\
(0.132)\end{array}$ \\
\hline Constant & $\begin{array}{l}-4.998^{* * * *} \\
(0.178)\end{array}$ & $\begin{array}{l}-0.848^{* * *} \\
(0.204)\end{array}$ & & $\begin{array}{l}-5.212^{* * *} \\
(0.218)\end{array}$ & $\begin{array}{l}-1.852^{* * *} \\
(0.244)\end{array}$ & $\begin{array}{l}-4.819^{* * *} \\
(0.179)\end{array}$ & $\begin{array}{l}-1.229^{* * *} \\
(0.241)\end{array}$ & $\begin{array}{l}-5.311^{* * *} \\
(0.199)\end{array}$ & $\begin{array}{l}-0.369 \\
(0.235)\end{array}$ \\
\hline Wald $\chi 2$ & $24,123.46$ & & & $10,373.22$ & & $20,042.28$ & & $35,452.61$ & \\
\hline Prob $>\chi^{2}$ & 0.000 & & & 0.000 & & 0.000 & & 0.000 & \\
\hline Pseudo-R2 & 0.215 & & & 0.122 & & 0.163 & & 0.256 & \\
\hline Log-likelihood & $-25,193.699$ & & & $-15,557.725$ & & $-22,481.975$ & & -16.412 .075 & \\
\hline Observations & 105,993 & & & 56,744 & & 101,749 & & 83,721 & \\
\hline
\end{tabular}

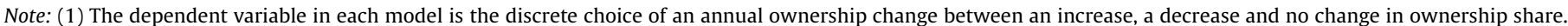
(2) The "No change" category is taken as the base group to which the estimates are compared with.

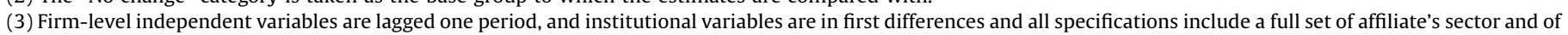
year dummies.

(4) Standard errors in parenthesis; ${ }^{*} \mathrm{p}<0.01$; $^{* *} \mathrm{p}<0.05 ;{ }^{* * *} \mathrm{p}<0.01$.

(5) The $\chi^{2}$ statistic compares the log-likelihood of the model with that of a "base" model containing only two alternative-specific constants.

(6) In Model 1, for variables of interest we add results of the post-estimation test of equality of coefficients, used to test our hypotheses.

We estimate a model of the likelihood of change in ownership control that takes the following form:

$y_{i t}^{*}=\mathbf{x}_{i t} \boldsymbol{\beta}+v_{i t} \quad i=1,2, \ldots, n$ and $t=1,2, . ., T$

$v_{i t}=\alpha_{i t}+u_{i t}$

$y_{i t}=1$ if $y *_{i t}>0$ and $=0$ otherwise

where $y_{i t}^{*}$ is a latent variable, the unobservable propensity for ownership control change in either direction (i.e. towards majority or towards minority), while $y$ is the observed outcome. The latency results from the fact that an investor may well wish to change the control structure it has in the affiliate, but it requires willing buyers or sellers and a functioning market for the event to occur. $\mathbf{x}_{i t}$ is the matrix of time varying and time invariant variables which are assumed exogenous with their influence on $y_{i t}^{*}$ with all host and home country level variables taken in first differences, and firmlevel variables lagged to avoid simultaneity, ${ }^{7} \beta_{i t}$ is the vector of parameters, $\alpha_{i t}$ is the individual unobservable effect and $u_{i t}$ is the random error. Given the multi-level data at our disposal, we allow for industry-specific fixed-effects $\left(v_{j} \eta\right)$. Our measures of both institutional quality and financial market development enter the model as changes in the values, such that we are relating the change in ownership structure to the change in institutional environments. We have 122 home countries and 125 host

\footnotetext{
${ }^{7}$ Equally, as we relate country level measures of institutional quality to firm level ownership structure, there is no potential endogeneity in institutional quality.
}

countries, and to avoid artificially boosting the significance of our country level effects we cluster standard errors on all homehost country combinations present in our data. This is a conservative approach to avoid over-stating the importance of country level effects. As robustness checks we also run a version of our models where standard errors are clustered on firms. Predictably the results concerning the tests of our Hypotheses 1 and 2 increase markedly in significance, while some of the significance on firm level variables become smaller. However, the significance and inferences concerning our various tests of Hypotheses 3 and 4 remain unchanged (results available on request).

As discussed, we model the process of change in ownership control as three discrete outcomes: a shift towards majority control by foreign investor, a shift towards minority control, and no such change. While our baseline captures the discrete change between minority and majority holding from the perspective of the foreign firm, we also conduct a complementary but distinct analysis based on changes in ownership shares. The justification of this approach is as follows. While the stress on ownership control fits our theoretical perspective best, it is possible for there to be sizeable changes in ownership structure that do not change the category; for example, changing the ownership of an affiliate from $90 \%$ to $60 \%$ still requires significant investment from a local partner, but would not be captured within the discrete category. This becomes important in terms of the application of property rights in the context of local institutional environments. An increase in local holding of this magnitude involves potentially the 
Table 4

Additional results: foreign affiliate ownership percentage changes (Multinomial logit regressions).

\begin{tabular}{|c|c|c|c|c|c|c|c|c|}
\hline \multirow[b]{2}{*}{ VARIABLES } & \multicolumn{2}{|c|}{ (1) Full sample } & \multicolumn{2}{|c|}{ (2) Without Wholly-owned } & \multicolumn{2}{|c|}{ (3) Without zeros } & \multicolumn{2}{|c|}{ (4) Europe only } \\
\hline & $\begin{array}{l}\text { Decrease } \\
\text { share }\end{array}$ & $\begin{array}{l}\text { Increase } \\
\text { share }\end{array}$ & $\begin{array}{l}\text { Decrease } \\
\text { share }\end{array}$ & $\begin{array}{l}\text { Increase } \\
\text { share }\end{array}$ & $\begin{array}{l}\text { Decrease } \\
\text { share }\end{array}$ & $\begin{array}{l}\text { Increase } \\
\text { share }\end{array}$ & $\begin{array}{l}\text { Decrease } \\
\text { share }\end{array}$ & Increase share \\
\hline Ownership share (t-1) & $\begin{array}{l}0.007^{* * *} \\
(0.001)\end{array}$ & $\begin{array}{l}-0.020^{* * *} \\
(0.001)\end{array}$ & $\begin{array}{l}0.011^{* * * *} \\
(0.001)\end{array}$ & $\begin{array}{l}-0.008^{* * *} \\
(0.001)\end{array}$ & $\begin{array}{l}0.005^{* * * *} \\
(0.001)\end{array}$ & $\begin{array}{l}-0.012^{* * *} \\
(0.001)\end{array}$ & $\begin{array}{l}0.005^{* * * *} \\
(0.001)\end{array}$ & $\begin{array}{l}-0.022^{* * *} \\
(0.001)\end{array}$ \\
\hline Relatedness with respect to Parent & $\begin{array}{l}-0.231^{* * *} \\
(0.034)\end{array}$ & $\begin{array}{l}-0.130^{* * *} \\
(0.034)\end{array}$ & $\begin{array}{l}-0.109^{* * *} \\
(0.040)\end{array}$ & $\begin{array}{l}-0.035 \\
(0.045)\end{array}$ & $\begin{array}{l}-0.236^{* * *} \\
(0.035)\end{array}$ & $\begin{array}{l}-0.155^{* * *} \\
(0.036)\end{array}$ & $\begin{array}{l}-0.214^{* * *} \\
(0.042)\end{array}$ & $\begin{array}{l}-0.086^{* *} \\
(0.036)\end{array}$ \\
\hline $\begin{array}{l}\text { Maturity: time since initial } \\
\text { investment }\end{array}$ & $\begin{array}{l}0.331^{* * *} \\
(0.045)\end{array}$ & $\begin{array}{l}0.179^{* * *} \\
(0.040)\end{array}$ & $\begin{array}{l}0.307^{* * *} \\
(0.060)\end{array}$ & $\begin{array}{l}0.216^{* * *} \\
(0.045)\end{array}$ & $\begin{array}{l}0.330^{* * *} \\
(0.045)\end{array}$ & $\begin{array}{l}0.203^{* * *} \\
(0.042)\end{array}$ & $\begin{array}{l}0.384^{* * *} \\
(0.050)\end{array}$ & $\begin{array}{l}0.329^{* * *} \\
(0.040)\end{array}$ \\
\hline International experience & $\begin{array}{l}0.004^{* * *} \\
(0.001)\end{array}$ & $\begin{array}{l}-0.011^{* * *} \\
(0.002)\end{array}$ & $\begin{array}{l}0.005^{* * *} \\
(0.001)\end{array}$ & $\begin{array}{l}-0.010^{* * *} \\
(0.003)\end{array}$ & $\begin{array}{l}0.004^{* *} \\
(0.002)\end{array}$ & $\begin{array}{l}-0.009^{* * *} \\
(0.002)\end{array}$ & $\begin{array}{l}0.004^{* * *} \\
(0.001)\end{array}$ & $\begin{array}{l}-0.007^{* * *} \\
(0.002)\end{array}$ \\
\hline Host country experience & $\begin{array}{l}0.006 \\
(0.005)\end{array}$ & $\begin{array}{l}0.000 \\
(0.011)\end{array}$ & $\begin{array}{l}-0.003 \\
(0.006)\end{array}$ & $\begin{array}{l}0.006 \\
(0.008)\end{array}$ & $\begin{array}{l}0.007^{*} \\
(0.004)\end{array}$ & $\begin{array}{l}0.002 \\
(0.010)\end{array}$ & $\begin{array}{l}0.008^{* *} \\
(0.003)\end{array}$ & $\begin{array}{l}0.003 \\
(0.009)\end{array}$ \\
\hline High tech dummy & $\begin{array}{l}0.293 \\
(0.206)\end{array}$ & $\begin{array}{l}-0.006 \\
(0.227)\end{array}$ & $\begin{array}{l}0.305 \\
(0.324)\end{array}$ & $\begin{array}{l}0.124 \\
(0.321)\end{array}$ & $\begin{array}{l}0.322 \\
(0.212)\end{array}$ & $\begin{array}{l}0.107 \\
(0.215)\end{array}$ & $\begin{array}{l}0.051 \\
(0.224)\end{array}$ & $\begin{array}{l}-0.160 \\
(0.262)\end{array}$ \\
\hline Subsidiary Profits & $\begin{array}{l}0.552^{* * *} \\
(0.045)\end{array}$ & $\begin{array}{l}0.507^{* * *} \\
(0.049)\end{array}$ & $\begin{array}{l}0.296^{* * *} \\
(0.041)\end{array}$ & $\begin{array}{l}0.328^{* * *} \\
(0.049)\end{array}$ & $\begin{array}{l}0.566^{* * *} \\
(0.045)\end{array}$ & $\begin{array}{l}0.543^{* * *} \\
(0.052)\end{array}$ & $\begin{array}{l}0.469^{* * *} \\
(0.051)\end{array}$ & $\begin{array}{l}0.443^{* * *} \\
(0.060)\end{array}$ \\
\hline Host Corruption & $\begin{array}{l}-0.331^{* * *} \\
(0.085)\end{array}$ & $\begin{array}{l}-0.145^{*} \\
(0.077)\end{array}$ & $\begin{array}{l}-0.127 \\
(0.090)\end{array}$ & $\begin{array}{l}-0.034 \\
(0.084)\end{array}$ & $\begin{array}{l}-0.315^{* * *} \\
(0.086)\end{array}$ & $\begin{array}{l}-0.131 \\
(0.081)\end{array}$ & $\begin{array}{l}-0.468^{* * *} \\
(0.104)\end{array}$ & $\begin{array}{l}-0.193^{* *} \\
(0.096)\end{array}$ \\
\hline Host Equity Market & $\begin{array}{l}-0.044 \\
(0.076)\end{array}$ & $\begin{array}{l}-0.091 \\
(0.081)\end{array}$ & $\begin{array}{l}-0.072 \\
(0.092)\end{array}$ & $\begin{array}{l}-0.141 \\
(0.091)\end{array}$ & $\begin{array}{l}-0.048 \\
(0.076)\end{array}$ & $\begin{array}{l}-0.046 \\
(0.088)\end{array}$ & $\begin{array}{l}-0.016 \\
(0.082)\end{array}$ & $\begin{array}{l}0.027 \\
(0.087)\end{array}$ \\
\hline Home Corruption & $\begin{array}{l}0.059 \\
(0.078)\end{array}$ & $\begin{array}{l}-0.229^{* * *} \\
(0.058)\end{array}$ & $\begin{array}{l}-0.0760 \\
(0.087)\end{array}$ & $\begin{array}{l}-0.241^{* * *} \\
(0.067)\end{array}$ & $\begin{array}{l}0.048 \\
(0.078)\end{array}$ & $\begin{array}{l}-0.207^{* * *} \\
(0.060)\end{array}$ & $\begin{array}{l}-0.024 \\
(0.090)\end{array}$ & $\begin{array}{l}-0.218^{* * *} \\
(0.064)\end{array}$ \\
\hline Home Equity Market & $\begin{array}{l}0.068 \\
(0.078)\end{array}$ & $\begin{array}{l}-0.078 \\
(0.064)\end{array}$ & $\begin{array}{l}0.113 \\
(0.086)\end{array}$ & $\begin{array}{l}-0.172^{* *} \\
(0.073)\end{array}$ & $\begin{array}{l}0.073 \\
(0.077)\end{array}$ & $\begin{array}{l}-0.037 \\
(0.066)\end{array}$ & $\begin{array}{l}-0.144^{*} \\
(0.087)\end{array}$ & $\begin{array}{l}-0.066 \\
(0.069)\end{array}$ \\
\hline Constant & $\begin{array}{l}-3.416^{* * * *} \\
(0.132)\end{array}$ & $\begin{array}{l}-1.149^{* * *} \\
(0.117)\end{array}$ & $\begin{array}{l}-3.506^{* * *} \\
(0.136)\end{array}$ & $\begin{array}{l}-1.792^{* * * *} \\
(0.138)\end{array}$ & $\begin{array}{l}-3.231^{* * *} \\
(0.135)\end{array}$ & $\begin{array}{l}-1.257^{* * *} \\
(0.122)\end{array}$ & $\begin{array}{l}-3.263^{* * *} \\
(0.158)\end{array}$ & $\begin{array}{l}-0.909^{* * *} \\
(0.126)\end{array}$ \\
\hline Wald $\chi^{2}$ & 12412.94 & & $6,321.67$ & & $10,870.58$ & & 19,222 & \\
\hline Prob $>\chi^{2}$ & 0.000 & & 0.000 & & 0.000 & & 0.000 & \\
\hline Pseudo-R2 & 0.107 & & 0.085 & & 0.101 & & 0.117 & \\
\hline Log-likelihood & $-71,053.193$ & & $-39,651.525$ & & $-67,832.215$ & & $-55,599.105$ & \\
\hline Observations & 105,993 & & 56,744 & & 101,749 & & 83,721 & \\
\hline
\end{tabular}

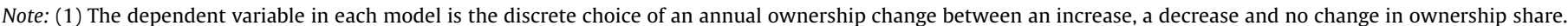
(2) The "No change" category is taken as the base group to which the estimates are compared with.

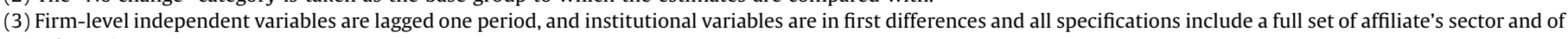
year dummies.

(4) Standard errors in parenthesis; ${ }^{*} \mathrm{p}<0.01$; ${ }^{* *} \mathrm{p}<0.05$; ${ }^{* * *} \mathrm{p}<0.01$.

(5) The $\chi^{2}$ statistic compares the log-likelihood of the model with that of a "base" model containing only two alternative-specific constants.

(6) In Model 1, for variables of interest we add results of the post-estimation test of equality of coefficients, used to test our hypotheses.

lowest cost of adjustment; there is no change in the final owner, but it may reflect the availability of local capital, or the need to further incentivise local partners. We therefore augment our initial analysis by estimating a model where outcomes are defined by an increase, no change and decrease in ownership share of foreign investor. In both cases we estimate a multinomial logit model, which considers the effects of firm characteristics on the probability of each of the choices. ${ }^{8}$

\section{Results}

We estimate four variants of equation 1 presented above and the results are in Tables 3 and 4 . Model 1 is estimated on the full sample. We perform a number of additional checks in Models 2-4.

\footnotetext{
${ }^{8}$ The multinomial logit model is a special case of the general logit model that allows for more than two outcomes. After estimating the parameters of the model, one can then predict the probability that an individual with a certain vector of characteristics will choose a certain outcome. An alternative strategy could be to model ownership change as a continuous dependent variable. However, the nature of the data renders that impossible. A large number of zero changes implies nonnormality, such that even if we did model the process as a continuous variable with lots of zeros, the results would not be credible.
}

In Model 2 we exclude wholly-owned affiliates. ${ }^{9}$ In Model 3 we exclude affiliates whose ownership falls to zero. Model 4 is restricted to Europe in order to investigate whether the results are affected by geography.

In order to evaluate the overall performance of our modelling and estimation strategy, we employ Wald tests to verify that we can reject the null hypothesis that the alternative choices in our dependent variable should be combined. This indeed cannot be rejected at the 0.001 significance level (Long \& Freese, 2014). Empirical support for our hypotheses is then based on the significance of the relevant coefficients for Hypotheses 1 and 2, and on post-estimation tests of differences in coefficients between the outcomes, evaluated for the variables of interest for Hypotheses 3 and 4 (all for the core Model 1).

Our results show clearly that we have support for all of our hypotheses based on property rights theory. In Hypothesis 1, we test two arguments contrasting property rights theory and transactions costs - agency theories. We find that an increase in host country corruption is strongly associated with a lower

\footnotetext{
${ }^{9}$ In the paper we consistently use the term "majority ownership", to simplify our terminology. However, where we include wholly owned majority ownership, the term “dominant ownership" as used by Gaur and Lu (2007) could probably fit better. An important point here is that shifts between wholly-owned structures and (simple) majority are common. That distinction is not clear-cut: a local peak in distribution of ownership is instead just above the 50\% ownership threshold, confirming the significance of the property rights/ownership control perspective. Driffield et al. (2014) offer further discussion of the shape of the distribution in ownership.
} 
likelihood of a shift towards minority ownership, which is in line with Hypothesis $1 \mathrm{~b}$, but not $1 \mathrm{a}$. This suggests that the increased risk of expropriation argument trumps the increased opacity argument, subject to proper restraint with which we should interpret any empirical results. In contrast, there is no effect of corruption on the likelihood of a move to majority holding.

Hypothesis 2 is strongly supported in that improvements in local equity markets make the shift towards foreign minority ownership more likely, compared with the shift towards majority ownership. Here our key argument has been that the relative importance of the foreign contribution decreases, and what we obtained is consistent with this.

The results from the estimation of the supplementary model (based on a change in ownership share) in contrast with the core model (change in majority-minority status) are informative here. The signs on the coefficient are consistent with the baseline (ownership category) model, but the significance reduces. We infer two things from this. Firstly, formal changes in majority-minority ownership control are a more meaningful feature of ownership changes than are mere changes in ownership within the category. Secondly, this finding confirms the property rights perspective to be the appropriate framework since this is linked to ownership control (decision rights) rather than to merely identifying the firms' relative rights to a future income stream.

Table 3, illustrates strong support for Hypothesis 3b (i.e. the alternative based on property rights theory) and Hypothesis 4: Increased experience makes adjustment towards minority foreign control more likely; and relatedness between the affiliate's and the parent's activities renders adjustment towards minority shares less likely and adjustment towards majority shares more likely.

Model 4 shows the results of isolating Europe from our sample. This confirms that our overall findings are robust to the distinction between within-continent linkages between MNEs and their affiliates, compared with linkages between MNEs and affiliates located in different continents. The rationale for undertaking the analysis for Europe is that it constitutes the largest part of our data.

In order to illustrate the relative magnitude of the effects, we combine the results for the four institutional variables (from Model 1 ) into one graph presented below as Fig. 2, which adopts a method developed by Long and Freese (2014) to visualise the multinomial model results in a concise way.

Here, the effects of the independent variables are represented in separate rows. The magnitude and sign of each of these is measured on the horizontal axis. The letters on the graphs indicate different outcomes of the dependent variable included in the multinomial model so that: D relates to a decrease in ownership share of the foreign parent company in its affiliate; I to an increase; and 0 to an outcome where there is no ownership change. There are two measures of the size and sign of the effects. The horizontal scale above the graph corresponds to the relative odds ratios for each of these outcomes, such that 1 on the horizontal axis represents a situation where a particular variable has no effect. An odds ratio below 1 implies a negative impact, and an odds ratio above 1 implies a positive impact. The distance from 1 can be taken as a measure of the strength of the effect, so for example the impact of one standard deviation increase in host country equity market effectiveness has twice as strong an effect as a similar magnitude decrease in the host country corruption indicator. The scale at the bottom of the graph represents the logit coefficients. Here, a coefficient value of 0 corresponds to the odds ratio of 1 on the upper scale.

The first row corresponds to host country corruption. Deterioration in the host country institutional quality (increase in corruption) has an ambiguous effect on the likelihood of a shift toward majority foreign control. In contrast, it has a strong effect on the likelihood of shifting the majority control to local partners.

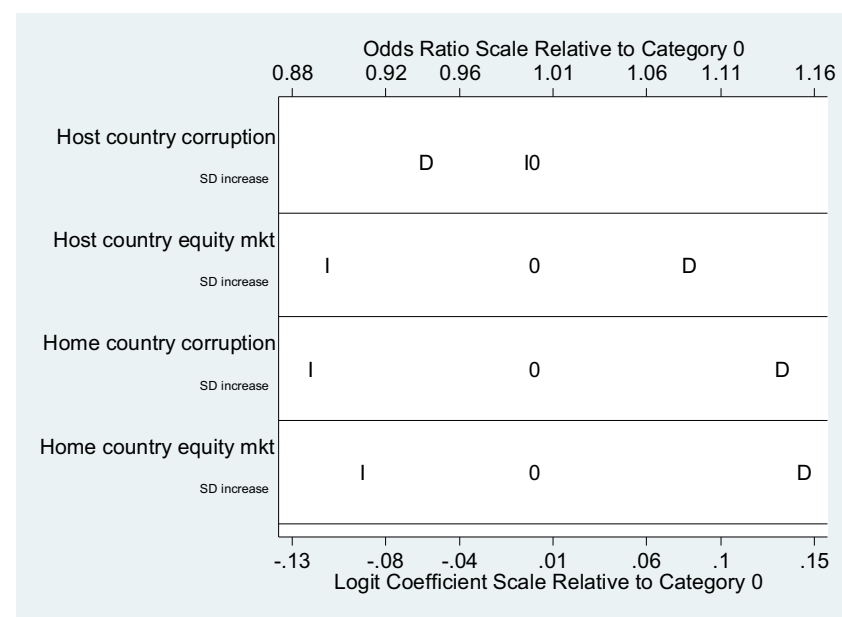

Fig. 2. Odds Ratios Plot for Explanatory Variables Related to Institutional Environment.

Note: D corresponds to decrease towards minority foreign ownership, I to increase towards majority foreign ownership, and 0 denotes no change.

This figure also demonstrates elegantly the comparative effects of home country changes. While a detailed discussion of these is beyond the scope of this paper, it is interesting to note that a change in home country corruption has an impact on ownership control shifts that is directionally opposite to that of host country corruption.

Hypothesis 2 suggests that an improvement in the host country's equity market quality will make a reduction in the share of foreign ownership more likely. This is supported. As illustrated by the second row of Fig. 2, the likelihood of increase towards majority share comes with large, negative coefficient (odd ratio below one). In contrast, the likelihood of decrease towards minority share comes with positive coefficient (odd ratio above one).

With respect to the home country equity market, we also find both coefficients significant. What is interesting to note is that the effect of the improved quality of the home country equity market is very strong on the likelihood of a decrease in foreign shareholding; it is the strongest effect of all that we found for institutional variables.

\section{Conclusions}

This paper explains a long standing disconnect in the literature concerning macro level institutional voids deterring FDI and locations with significant voids still attracting significant amounts of FDI. To resolve this issue we adopt a perspective, which enables us to analyse both the institutional environment and firm level characteristics as part of the integrated framework. The key question relates to the value of the relative contribution of the partners and to the outside options they possess. We examine the evolution of ownership structure of foreign affiliates in the context of institutional voids, both in terms of the standard measure of institutional quality, and also in terms of equity market development. Firm level factors we consider are relatedness and maturity of the JV. We argue that the ownership control structure adjusts, because changes in both the environment and in partners' characteristics imply changes in the value of their contribution: the response, in the form of a change in the affiliate's ownership structure, is conditioned both by the value of the relative contributions of foreign and local partners and by their outside options (De Meza \& Lockwood, 1998). 
Generally, focusing on change, we respond to the call to arms of Hennart and Slangen (2014), who emphasise the need for greater understanding of the post-entry ownership evolution. We argue that the desired level of a foreign firm's commitment to a host country or to a project may change over time. Indeed, the Uppsala framework by Johanson and Vahlne (1977, 2009) emphasises experiential learning and the evolutionary aspects of the process of adjustment. Though we adopt a different framework, we contribute to the same discussion while predicting different outcomes (especially in Hypothesis 3b as contrasted with 3a).

This study is a first preliminary step into the direction of building a richer theory, linking changes in institutional voids to evolution in MNE ownership structure. This is needed as both the wider institutional system and the financial sub-system aspects of institutional quality impact on these strategies. In this paper we take the existing ownership structure as a boundary control condition, and - to the best of our knowledge - make the first step towards building a theory that focuses on adjustment processes in ownership control, demonstrating the importance of both firm level and institutional characteristics under a consistent framework of the property rights approach. We stress that ownership control should belong to those whose behaviour most affects the value of the venture on the margin, and to those who are more sensitive to the outside options (De Meza \& Lockwood, 1998).

Our findings suggest a number of directions for further work. Firstly, the precise nature of the adjustment process in ownership needs to be explored further by bridging the IB, economics, and finance literatures to highlight the importance of control and governance structures for firm performance. For example, the level of dynamic capabilities (Cantwell \& Mudambi, 2005; Prange \& Verdier, 2011; Rugman \& Verbeke, 2001), the nature of the embededness of affiliates (Kafouros, Buckley, \& Clegg, 2012; Meyer et al., 2011; Nobel \& Birkinshaw, 1998), and the organisational learning within the MNE network (Andersson, Björkman, \& Forsgren, 2005; Mudambi, 2002; Oddou, Osland, \& Blakeney, 2009) may inform us on the additional drivers of post-entry behaviour and their relative importance vis-à-vis evolving institutional quality. Taken together, our findings also post some interesting challenges for the literature which seeks to build on Chang, Chung, and Moon (2013) comparing the respective performance of ventures with different ownership structure. We highlight that comparing JVs with wholly owned affiliates, merely provides a picture at a point in time, rather than an indication of the optimal evolution of a given ownership structure. The challenge is to link this evolution of ownership structure to subsequent performance. This in turn offers a number of insights for managers of MNEs. As host country equity markets improve, local firms are better able to use them, which erodes the MNE's inherent advantage in terms of access to finance. In order to sustain a competitive advantage, it is important for MNEs to continue to support subsidiary development, and encourage multiple embeddedness of its affiliates as host countries develop.

As financial markets improve, they can also provide important feedback to the MNE in terms of reliable signals and responses to investment decisions. This reduces the need for control in the form of high ownership levels, and makes a decrease in the ownership share of foreign partners more likely; this effect runs in parallel to the improvement in the broader institutional environment. Interestingly, as illustrated by Fig. 2, in terms of relative magnitude of the effects, the quality of the host equity markets we stress here dominates over the general institutional quality of the host country, albeit both remain important. This however presents a challenge for the multinational, in terms of encouraging further development of its affiliates, in the form of both organic growth, but also via providing further, and possibly different, resources from the parent company, while resolving the question if reducing ownership stakes will be optimal.

Presence of such ambiguities and dilemmas, in a wider context, highlight the contribution that property rights analysis can make to IB theory. We demonstrated, while motivating and testing our hypotheses, that the property rights theory leads to sharper predictions than some alternative theories.

Our analysis also highlights the need for a better understanding of the relative importance of public policy and private investment in improving both institutional quality and firm performance in emerging markets. Work is also needed to further link our findings to the empirical literature on international technology transfer and spillovers. It is reasonable to assume that technology transfer from parent to affiliate increases with the size of the parental investment. This cannot therefore be divorced from the evolution of ownership structures, either in terms of the theoretical treatments of technology transfer, but also in the capacity for developing countries to attract foreign investment in order to connect to global technology and improve competitiveness. We hope that some of these issues are explored further in order to understand the complex nature of the adjustment process in ownership.

\section{References}

Aghion, P., \& Holden, R. (2011). Incomplete contracts and the theory of the firm: What have we learned over the past 25 years? The Journal of Economic Perspectives, 25(2), 181-197.

Aguilera, R. V., \& Crespi-Cladera, R. (2016). Global corporate governance: On the relevance of firms' ownership structure. Journal of World Business, 51(1), 50-57.

Ambos, T. C., Andersson, U., \& Birkinshaw, J. (2010). What are the consequences of initiative-taking in multinational subsidiaries\&quest. Journal of International Business Studies, 41(7), 1099-1118.

Andersson, U., Björkman, I., \& Forsgren, M. (2005). Managing subsidiary knowledge creation: The effect of control mechanisms on subsidiary local embeddedness. International Business Review, 14(5), 521-538.

Andersson, U., Forsgren, M., \& Holm, U. (2007). Balancing subsidiary influence in the federative MNC: A business network view. Journal of International Business Studies, 38(5), 802-818.

Antràs, P. (2005). Incomplete contracts and the product cycle. American Economic Review, 95(4), 1054-1073.

Antràs, P. (2014). Grossman-Hart (1986) goes global: Incomplete contracts, property rights, and the international organization of production. Journal of Law, Economics, and Organization, 30(Suppl. 1), i118-i175.

Baker, M., Foley, C. F., \& Wurgler, J. (2008). Multinationals as arbitrageurs: The effect of stock market valuations on foreign direct investment. Review of Financial Studies, 22(1), 337-369.

Beamish, P. W., \& Lupton, N. C. (2016). Cooperative strategies in international business and management: Reflections on the past 50 years and future directions. Journal of World Business, 51(1), 163-175.

Benito, G. R. G., Petersen, B., \& Welch, L. S. (2009). Towards more realistic conceptualisations of foreign operation modes. Journal of International Business Studies, 40, 1455-1470.

Birkinshaw, J. M., \& Morrison, A. J. (1995). Configurations of strategy and structure in subsidiaries of multinational corporations. Journal of International Business Studies, 41(7), 729-753.

Bishop, K., Filatotchev, I., \& Mickiewicz, T. (2002). Endogenous ownership structure. Acta Oeconomica, 52(4), 443-471.

Boddewyn, J. J. (1983). Foreign and domestic divestment and investment decisions: Like or unlike? Journal of International Business Studies23-35.

Brouthers, K. D., \& Bamossy, G. (1997). The role of key stakeholders in international joint venture negotiations: Cases from Eastern Europe. Journal of International Business Studies, 28, 285-308.

Brouthers, K. D. (2002). Institutional, cultural and transaction cost influences on entry mode choice and performance. Journal of International Business Studies, 33 (2), 223-231.

Brouthers, K. D. (2013). A retrospective on: Institutional, cultural and transaction cost influences on entry mode choice and performance. Journal of International Business Studies, 44(1), 14-22.

Buckley, P. J., \& Casson, M. (2010). The multinational enterprise revisited. Haundsmills: Palgrave Macmillan.

Cantwell, J. A., \& Mudambi, R. (2005). MNE competence-creating subsidiary mandates. Strategic Management Journal, 26, 1109-1128.

Cantwell, J. A., Dunning, J. H., \& Lundan, S. M. (2010). An evolutionary approach to understanding international business activity: The co-evolution of MNEs and the institutional environment. Journal of International Business Studies, 41(4), 567-586. 
Carson, S. J., \& John, G. (2013). A theoretical and empirical investigation of property rights sharing in outsourced research, development, and engineering relationships. Strategic Management Journal, 34(9), 1065-1085.

Chang, S. J., Chung, J., \& Moon, J. J. (2013). When do wholly owned subsidiaries perform better than joint ventures? Strategic Management Journal, 34(3), 317337.

Claessens, S., Demirgüc-Kunt, A., \& Huizinga, H. (2001). How does foreign entry affect domestic banking markets? Journal of Banking E Finance, 25(5), 891-911.

Cuervo-Cazurra, A. (2006). Who cares about corruption? Journal of International Business Studies, 37, 807-822.

Cuervo-Cazurra, A. (2016). Corruption in international business. Journal of World Business, 51(1), 35-49.

Cuervo-Cazzura, A., \& Dau, L. A. (2009). Promarket reforms and firm profitability in developing countries. Academy of Management Journal, 52(6), 1348-1368.

Dau, L., \& Cuervo-Cazurra, A. (2014). To formalize or not to formalize: Entrepreneurship and pro-market institutions. Journal of Business Venturing, 29 (5), 668-686.

De Meza, D., \& Lockwood, B. (1998). Does asset ownership always motivate managers? Outside options and the property rights theory of the firm. Quarterly Journal of Economics, 113(2), 361-386.

Driffield, N., Love, J. H., \& Menghinello, S. (2010). The multinational enterprise as a source of international knowledge flows: Direct evidence from Italy. Journal of International Business Studies, 41(2), 350-359.

Driffield, N., Mickiewicz, T., \& Temouri, Y. (2013). Institutional reforms productivity and profitability: From rents to competition? Journal of Comparative Economics, 41(2), 583-600.

Driffield, N., Mickiewicz, T., \& Temouri, Y. (2014). Institutions and equity structure of foreign affiliates. Corporate Governance: An International Review, 22(3), 216-229.

Driffield, N., Love, J. H., \& Yang, Y. (2016). Reverse international knowledge transfer in the MNE:(Where) does affiliate performance boost parent performance? Research Policy, 45(2), 491-506.

Eden, L., \& Miller, S. R. (2004). In M. Hitt, \& J. Cheng (Eds.), Distance matters: Liability of foreignness, institutional distance and ownership strategy: (Vol. 16. pp. 187221).Advance in International Management, Emerald.

Estrin, S., Korosteleva, J., \& Mickiewicz, T. (2013). Which institutions encourage entrepreneurial growth aspirations? Journal of Business Venturing, 28(4), 564580.

Fang, Y., Wade, M., Delios, A., \& Beamish, P. W. (2013). An exploration of multinational enterprise knowledge resources and foreign subsidiary performance. Journal of World Business, 48(1), 30-38.

Feenstra, R. C., \& Hanson, G. H. (2005). Ownership and control in outsourcing to China: Estimating the property-rights theory of the firm. The Quarterly Journal of Economics, 120(1), 729-761.

Gans, J. S. (2005). Markets for ownership. RAND Journal of Economics, 36, 433-445.

Gaur, A. S., \& Lu, J. W. (2007). Ownership strategies and survival of foreign subsidiaries: Impacts of institutional distance and experience. Journal of Management, 33(1), 84-110.

Glaeser, E., Johnson, S., \& Shleifer, A. (2001). Coase versus the coasians. Quarterly Journal of Economics, 116, 853-899.

Globerman, S., \& Shapiro, S. (2003). Governance infrastructure and US foreign direct investment. Journal of International Business Studies, 34, 19-39.

Grossman, S., \& Hart, O. (1986). The costs and benefits of ownership. Journal of Political Economy, 94(4), 691-719.

Habib, M., \& Zurawicki, L. (2002). Corruption and foreign direct investment. Journal of International Business Studies, 33(2), 291-307.

Hart, O. (1995). Firms, contracts, and financial structure. Oxford: Oxford University Press.

Henisz, W. (2000). The institutional environment for multinational investment. Journal of Law, Economics and Organization, 16, 334-364.

Hennart, J. F., \& Slangen, A. H. L. (2014). Yes, we really do need more entry mode studies. Journal of International Business Studies, 46, 114-122.

Hoskisson, R. E., Wright, M., Filatotchev, I., \& Peng, M. W. (2013). Emerging multinationals from mid-Range economies: The influence of institutions and factor markets. Journal of Management Studies, 50, 1295-1321.

Huang, Y. (2003). Selling China. Foreign direct investment during the reform era. Cambridge: Cambridge University Press.

Javorcik, B. S., \& Wei, S. J. (2009). Corruption and cross-border investment in emerging markets: Firm-level evidence. Journal of International Money and Finance, 28, 605-624.
Johanson, J., \& Vahlne, J. E. (1977). The internationalization process of the firm-a model of knowledge development and increasing foreign market commitments. Journal of International Business Studies, 8(1), 23-32.

Johanson, J., \& Vahlne, J. E. (2009). The Uppsala internationalization process model revisited: From liability of foreignness to liability of outsidership. Journal of International Business Studies, 40, 1411-1431.

Kafouros, M. I., Buckley, P. J., \& Clegg, J. (2012). The effects of global knowledge reservoirs on the productivity of multinational enterprises: The role of international depth and breadth. Research Policy, 41, 848-861.

Khanna, T., \& Palepu, K. G. (1999). The right way to restructure conglomerates in emerging markets. Harvard Business Review, 77(4), 125-134.

Khanna, T., \& Palepu, K. G. (2010). Winning in emerging markets: A roadmap for strategy and execution. Boston, MA: Harvard Business Press Books.

Khoury, T. A., \& Peng, M. W. (2011). Does institutional reform of intellectual property rights lead to more inbound FDI in developing countries? Evidence from Latin America and the Caribbean. Journal of World Business, 46, 337-345.

Kogut, B. (1988). A study of the life cycle of joint ventures. Management International Review, 28(4), 39-52.

Lahiri, S., Elango, B., \& Kundu, S. K. (2014). Cross-border acquisition in services: Comparing ownership choice of developed and emerging economy MNEs in India. Journal of World Business, 49(3), 409-442.

Lien, Y. C., \& Filatotchev, I. (2015). Ownership characteristics as determinants of FDI location decisions in emerging economies. Journal of World Business, 50(4), 637 650.

Long, J. S., \& Freese, J. (2014). Regression Models for categorical Dependent Variables Using Stata. College Station, TX: Stata Press.

Makhija, M., \& Stewart, A. (2002). The effect of the institutional environment on perceptions of risk: A comparison of planned versus free-market managers. Journal of International Business Studies, 33(4), 737-757.

Malhotra, S., \& Gaur, A. S. (2014). Spatial geography and control in foreign acquisitions. Journal of International Business Studies, 45(2), 191-210.

Maskin, E., \& Tirole, J. (1999). Two remarks on the property-rights literature. Review of Economic Studies, 66, 139-149.

Meyer, K. E., Mudambi, R., \& Narula, R. (2011). Multinational enterprises and local contexts: The opportunities and challenges of multiple embeddedness. Journal of Management Studies, 48(2), 235-252.

Milgrom, P., \& Roberts, J. (1992). Organization and management. Englewood Cliffs: Prentice Hall.

Mudambi, R. (2002). Knowledge management in multinational firms. Journal of Management Studies, 8, 1-9.

Nobel, R., \& Birkinshaw, J. (1998). Innovation in multinational corporations: Control and communication patterns in international R\&D operations. Strategic Management Journal, 19(5), 479-496.

North, D. C. (1990). Institutions, institutional change and economic performance. Cambridge: Cambridge University Press.

Oddou, G., Osland, J. S., \& Blakeney, R. N. (2009). Repatriating knowledge: Variables influencing the transfer process. Journal of International Business Studies, 40, $181-199$.

Peng, M. W., \& Heath, P. S. (1996). The growth of the firm in planned economies in transition: Institutions, organisations, and strategic choice. Academy of Management Journal, 21(2), 492-528.

Peng, M. W., \& Su, W. (2014). Cross-listing and the scope of the firm. Journal of World Business, 49, 42-50.

Peng, M. W., Lee, S.-H., \& Wang, D. (2005). What determines the scope of the firm over time? A focus on institutional relatedness. Academy of Management Review, 30, 622-633.

Prange, C., \& Verdier, S. (2011). Dynamic capabilities, internationalization processes and performance. Journal of World Business, 46, 126-133.

Rugman, A. M., \& Verbeke, A. (2001). Subsidiary-specific advantages in multinational enterprises. Strategic Management Journal, 22, 237-250.

Tanzi, V. (1998). Corruption around the world: Causes consequences, scope, and cures. IMF Staff Papers, 45(4), 559-594.

Williamson, O. (1985). Economic institutions of capitalism. New York: Basic Books.

Zhao, J. H., Kim, S. H., \& Du, J. (2003). The impact of corruption and transparency on foreign direct investment: An empirical analysis. Management International Review, 43(1), 41-62.

Zhou, Y. M. (2014). Supervising across borders: The case of multinational hierarchies. Organization Science, 26(1), 277-292. 